\title{
The demography of the lizard Tropidurus torquatus (Squamata, Tropiduridae) in a highly seasonal Neotropical savanna
}

\author{
Helga C. Wiederhecker ${ }^{1}$, Adriana C. S. Pinto ${ }^{1}$, Marcela S. Paiva ${ }^{1}$, and Guarino R. Colli² \\ ${ }^{1}$ Departamento de Ecologia, Universidade de Brasília, Brasília-DF, 70910-900, Brazil. E-mail: helga@unb.br. \\ 2 Departamento de Zoologia, Universidade de Brasília, Brasília-DF, 70910-900, Brazil.
}

\begin{abstract}
The demography of the lizard Tropidurus torquatus (Squamata, Tropiduridae) in a highly seasonal Neotropical savanna. The demography of a population of Tropidurus torquatus was studied from March 1996 until December 1998, in the Cerrado biome of central Brazil, using the method of capture and recapture. Population size, number of incoming individuals in the population, and age structure varied seasonally, reflecting the reproductive cycle of the species. The instantaneous rate of population increase did not differ from zero throughout the study. In general, the permanence rates of juveniles and adults were low, indicating a large turnover of individuals in the population, with a maximum life expectancy of three years. The sex-ratio among adults was biased toward females. Since no bias was observed among juveniles and there was no difference in adult permanence between sexes, we suggest that the biased adult sex-ratio resulted from a lower permanence of males during a short ontogenetic period, when secondary sexual characteristics develop. When compared to $T$. itambere, the studied population of $T$. torquatus attained a higher density and a greater female bias in the sex-ratio. In general, the studied population presented characteristics that, according to life history theory, should be associated with early age at maturity and polygyny: short life expectancy, high population turn over, and female biased sex-ratios.
\end{abstract}

Keywords: Squamata, Tropiduridae, Tropidurus torquatus, demography, population structure, sex-ratio, central Brazil.

\section{Introduction}

The number of studies on lizard ecology has increased greatly since 1960 (Huey et al. 1983), improving our knowledge on the evolution of life history characteristics, one of the most important tools for understanding the diversity

Received 27 May 2003

Accepted 20 July 2003

Distributed 31 October 2003 and complexity of life cycles (Stearns 1992). The life history of a species can be summarized by demographic parameters such as birth and death rates, migratory movements, and population structure throughout time, as they deal with the interaction between longevity, reproductive age, growth pattern, and agespecific mortality versus the environment (Zug 1993). Interactions among these parameters throughout life make the demography of 
populations subject to constant variation through time. The demography of lizard populations can be influenced by various factors, such as temperature (Adolph and Porter 1993, Parker 1994), precipitation (Andrews 1988, Bull 1994), food availability (Ballinger 1977, Howland 1992, Smith 1996), and morphological and phylogenetic constraints (Ballinger 1983).

Some patterns can be singled out relating the dynamics and structure of populations to life history characteristics (Tinkle 1969). Lizards with delayed sexual maturity tend to have longer life cycles, along with major energetic investments in maintenance instead of reproduction (Tinkle 1969, Tinkle et al. 1970), and lower adult mortality (Hasegawa 1990, Bull 1995). Lizards with early sexual maturity have shorter life cycles and higher mortality rates for young and adults (Ballinger and Congdon 1981, Andrews and Nichols 1990), resulting in a larger population turnover (Ferguson et al. 1980, Tinkle et al. 1993). This dichotomy represents the extremes of a gradient, but many intermediate combinations exist (Dunham et al. 1988). The population structure can also be influenced by the mating system. Populations with higher incidences of polygyny tend to have higher male death rates than populations where polygyny is reduced (Schoener and Schoener 1980, Stamps 1983), generating a female biased sex-ratio. Life history theory, however, was developed mainly from data of temperate lizard species (Ballinger 1983) but, in tropical regions, which harbor the largest lizard diversity, longterm studies of population dynamics are scarce (e.g., Rocha and Bergallo 1992, Van Sluys 1993b, Rocha 1998).

The genus Tropidurus ranges from tropical to temperate South America, east of the Andes (Frost 1992). The torquatus group consists of abundant diurnal species located in various types of open formations (Rodrigues 1987). The ecology and reproductive cycles of some species have already been studied, including $T$. etheridgei (Cruz 1997), T. hispidus (Vitt and Goldberg 1983, Vitt et al. 1996), T. oreadicus
(Rocha and Bergallo 1990), T. itambere (Van Sluys 1993a, b, Van Sluys et al. 1994), and T. torquatus (Bergallo and Rocha 1993, 1994, Giaretta 1996). However, demographic studies exist only for T. itambere (Van Sluys 2000).

Tropidurus torquatus Wied is a seasonal breeder, with reproduction occurring from August to January (Vieira et al. 2001, Wiederhecker et al. 2002). Sexual maturity is reached in less than six months, and males are territorial and polygynous (Pinto 1999). Therefore, according to life history theory (Ballinger 1983, Dunham et al. 1988) it is expected that this species has a life history characterized by a short life cycle and populations with large turnover, high seasonal variation in size, and biased sex-ratios. Herein we identify temporal patterns of variation in population size, age structure, and sex-ratio of T. torquatus in the Cerrado of central Brazil, and make comparisons with a congeneric species, to evaluate predictions of current life history theory.

\section{Materials and Methods}

We carried out the study in Brasília, Brazil $\left(15^{\circ} 54^{\prime} 05^{\prime \prime} \mathrm{S}, 047^{\circ} 56^{\prime} 18^{\prime \prime} \mathrm{W}\right)$. The climate is Aw following Köppen's classification (Haffer 1987). It has a pronounced concentration of rain from October to April and annual mean temperature $\left(21.2^{\circ} \mathrm{C}\right)$ is relatively constant year-round.

We studied a population of $T$. torquatus along a transect of $313 \mathrm{~m}$ with mean width of $10 \mathrm{~m}\left(3130 \mathrm{~m}^{2}\right)$. This transect was isolated from any other area with a high density of the species. It was surrounded by a road on one side and by a gallery forest and a small lake, associated with the Santuário Ecológico do Riacho Fundo, on the other side. Another lizard, Ameiva ameiva (Teiidae), and several other potential predators were also recorded in the transect such as coati (Nasua nasua), brown capuchin (Cebus apella), guira cuckoo (Guira guira) and false coral snake (Oxyrhopus trigeminus). 
We collected lizards weekly with a noose from March 1996 to December 1998, with the exception of September 1996, February 1997 and 1998, and July 1998. We measured, sexed, and marked all captured lizards and released them at the capture site. We measured snoutvent length (SVL) with a ruler to the nearest mm. We made two kinds of marks on each lizard: an individual and permanent mark with digit clipping, avoiding the use of more than one digit per limb, and a temporary mark, a small nail polish spot on the dorsum, at the base of the tail. We used a different color each week to avoid recaptures during the same week. We determined sex only for adult individuals (males: SVL > $70 \mathrm{~mm}$; females: SVL > $65 \mathrm{~mm}$ ) (Wiederhecker et al. 2002), using the ventral coloration typical of adult males (Pinto 1999).

Mark-recapture data were used to estimate monthly population size, permanence rates, and number of incoming individuals, including standard errors, using a model of the Jolly-Seber type implemented by the freeware POPAN 4 (Arnason et al. 1995). Jolly-Seber models are widely applied for population analysis and estimate population parameters based on the history of captures and recaptures of individuals from a population (details on Jolly 1965). We used a modified version of the Jolly-Seber full model, developed to estimate parameters of open populations (with births, deaths, and exchange of individuals with other populations), allowing for possible heterogeneity among individuals in the loss rate, implemented by POPAN 4 (Arnason et al. 1995). The model assumptions are the following: unequal probability of capture among individuals, no tag loss, and no temporary migration. Since we analyzed data from more than one cohort and mortality tends to be higher among juveniles than among adults, the model well suited our data when considering the heterogeneity of the loss rate (Arnason et al. 1995). The model cannot estimate population size in the first and last months, therefore they are equal to zero in the graphs but this is not a valid estimation.
We calculated the instantaneous rate of natural increase $(r)$ for each month as: $r=\ln \left(N_{t+1}\right.$ / $N_{t}$ ), where $N_{t}$ is the population size at time $t$ and $N_{t+1}$ is the population size at time $t+1$ (Stearns 1992). To test if the $r$ value for each year and for the whole study period differed from zero, we used the Student's $t$-test (Zar 1984). We estimated population age structure and recruitment period by the monthly distribution of SVL for captured lizards.

To analyze cohort data for 1996, 1997, and 1998, we used the Jolly-Seber model without incoming individuals (birth and immigration). The model assumptions are the following: absence of new individual entries, maintenance of individual marks, and absence of temporary migration. This simplified model option reduces the number of demographic parameters, increasing the precision of the estimated values (Arnason et al. 1995), being appropriate since reproduction of $T$. torquatus is seasonal and recruitment is restricted to a short period.

We compared permanence rates between males and females from the end of one reproductive season to the beginning of next with a Student's t-test (Zar 1984). The estimates were calculated for two population subsets: all adults and cohort from 1996. All lizards captured in one reproductive season and recaptured during or after the next reproductive event were considered as persistent. To compare permanence rate between juveniles and adults we estimated the rate for both groups from the recruitment period to the first month of each year in which no juveniles were registered, using the Student's $t$-test. We considered as adults individuals with a SVL equal to or greater than the minimum reproductive size.

To obtain the sex-ratio, we compared the population sizes of males and females considering all captured adults using a chisquare test (Zar 1984). We obtained additional data on the juvenile sex-ratio from dissected lizards collected from October 1997 to September 1998 in Brasilia and surroundings (Wiederhecker et al. 2002). 
To conduct statistical analyses we used Systat v. 5.2 for Macintosh employing a significance level of $5 \%$ in all tests. Throughout the text we report means $(\bar{x})$ followed by \pm one standard deviation, while the estimated population parameters are followed by \pm one standard error.

\section{Results}

During the sample period we made 821 captures of 413 individuals: 74 males, 116 females, and 223 juveniles. About $60 \%$ of the individuals were captured only once, $65 \%$ of which were juveniles. Population size varied from 18 to 257 individuals during the study period (Figure 1). In each year a population peak occurred from April to June, followed by a steady decline. The smallest population sizes occurred from December 1996 to February 1997, and from November 1997 to March 1998. Mean density was $406.0 \pm 60.0$ individuals/ha in $1996,256.0$ \pm 39.2 individuals/ha in $1997,276.8 \pm 73.7$ individuals/ha in 1998 , and $307.4 \pm 34.7$ individuals/ha during the whole study period.

Variation in the number of incoming individuals in the population was associated with variation of population size (Figure 1). In all years, maximum values for entry rate occurred before population size peaks, with minimum values occurring in December. However, the permanence rate oscillated across months (Figure 1), with no evident pattern associated with population size. The instantaneous rate of natural increase of the population varied from -0.9 to 1.8 , with mean values for each year separately, and for the whole study, showing no significant difference from zero (Table 1). Population age structure varied seasonally (Figure 2). Adults were captured in all months, but recently hatched individuals, with SVL $<40 \mathrm{~mm}$, occurred only from March to June. After November, most captured individuals were larger than $80 \mathrm{~mm}$ during the three years.

The variation in population size for the

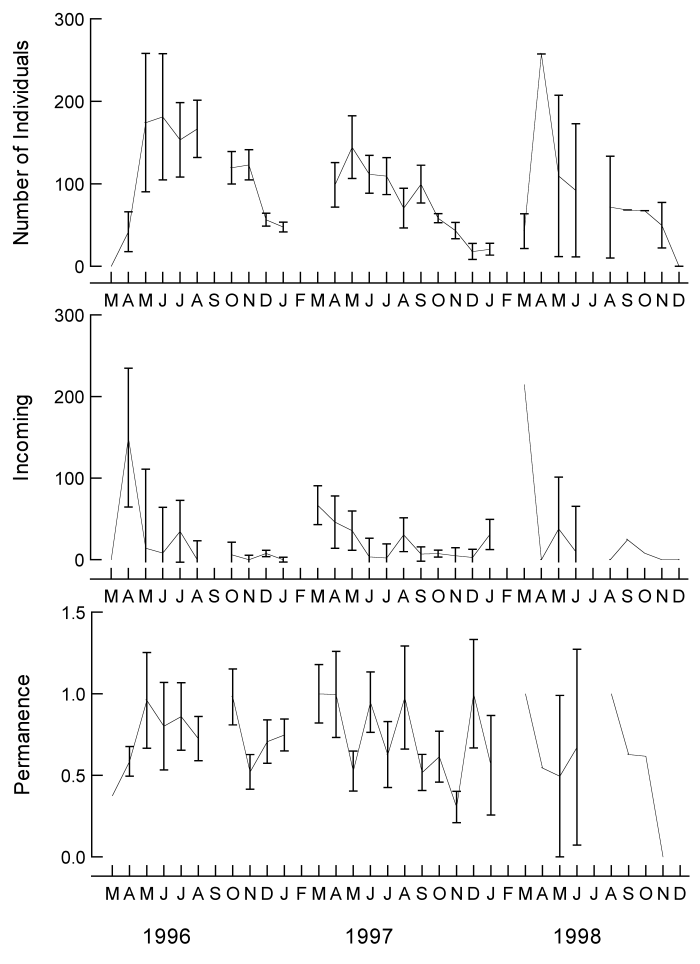

Figure 1 - Monthly distribution of estimates and standard errors of population size (top), rate number of incoming individuals (center), and permanence rate (bottom) of a population of Tropidurus torquatus from Brasília, Brazil, between March 1996 and December 1998.

cohorts of 1996, 1997, and 1998 presented similar patterns (Figure 3). The initial estimated size for the cohorts was $191 \pm 77$ in 1996, 207 \pm 63 in 1997 , and $146 \pm 50$ in 1998. A large portion of individuals disappeared from population before the first reproductive season in September (73\% in 1996, 88\% in 1997, and $90 \%$ in 1998), and few remained in the population during two or more years. In total, for 112 captured individuals from 1996 cohort, only two individuals, a female and a male, were recaptured in 1998. The longest life expectancy registered was three years, with no adults captured in 1996 being recaptured after the first 


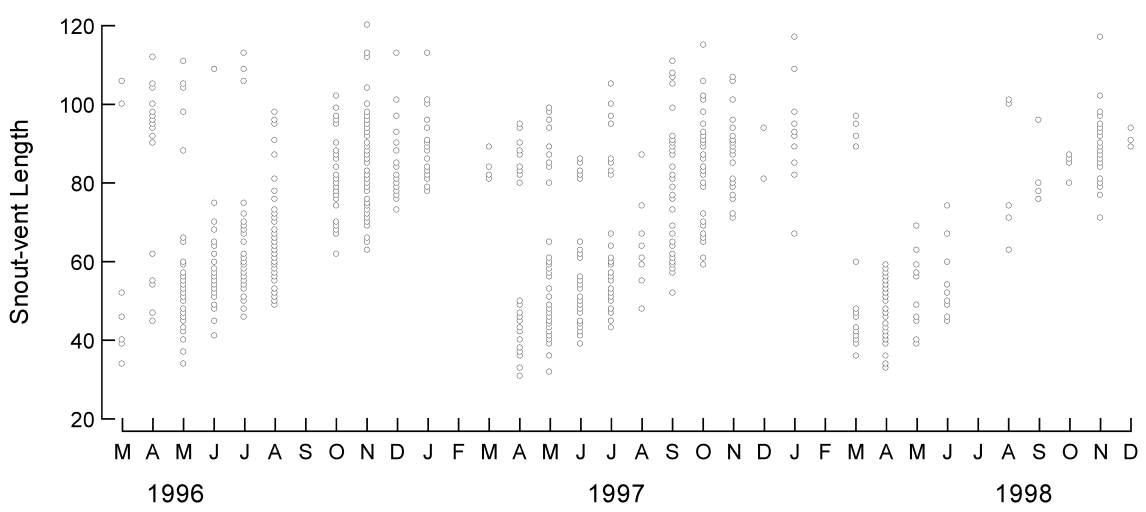

Figure 2 - Monthly distribution of snout-vent length of captured individuals of a population of Tropidurus torquatus from Brasília, Brazil, between March 1996 and December 1998.

half of 1998. Permanence rates for juveniles, from recruitment until adulthood, in 1996 and in 1998 were significantly lower than adult rates (Table 2). In 1997, however, there was no significant difference between permanence rates for juveniles and adults.

The sex-ratio, calculated from the total number of captured females (116) and males (74), differed statistically from $1: 1\left(\chi^{2}=9.28\right.$, $\mathrm{p}=0.002)$, there being a bias toward females. Among the dissected juveniles, however, the sex-ratio was not significantly different from 1:1 (males: 21 , females: $29 ; \chi^{2}=1.28, \mathrm{p}=0.261$ ). There were no significant difference between permanence rates of adult females and males in all tested intervals (Tables 3 and 4).

\section{Discussion}

During the study period, the population size of Tropidurus torquatus varied markedly, but the seasonal pattern of abundance was similar among years. The absence of a cyclical pattern in the permanence rate, coupled with the association between population size and recruitment rate, suggest that the variation in population size is a consequence of the seasonal reproductive cycle of this species (Wiederhecker et al. 2002). Furthermore, the occurrence of

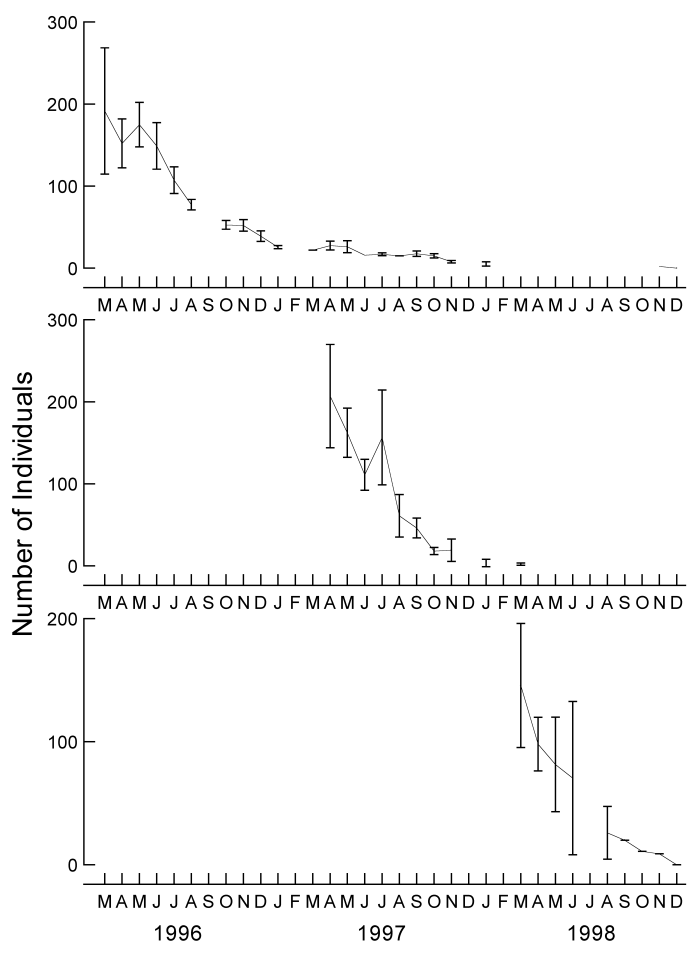

Figure 3 - Monthly distribution of estimates and standard errors of number of individuals in cohorts of 1996 (top), 1997 (center), and 1998 (bottom) of a population of Tropidurus torquatus from Brasília, Brazil, between March 1996 and December 1998. 
Table 1 - Mean value of instantaneous rate of natural increase $(r)$ and $t$-test results $\left(\mathrm{H}_{0}: r=0\right)$ of a population of Tropidurus torquatus from Brasília, Brazil. SE, standard error.

\begin{tabular}{cccc}
\hline Period & Mean $\boldsymbol{r}(\mathbf{S E}) / \mathbf{N}$ & $\mathbf{t}$ & $\mathbf{p}$ \\
\hline March to December 1996 & $0.105(0.295) / 6$ & 0.356 & 0.736 \\
January to December 1997 & $-0.208(0.135) / 9$ & -1.549 & 0.160 \\
January to December 1998 & $0.161(0.235) / 7$ & 0.495 & 0.638 \\
March 1996 to December 1998 & $-0.006(0.139) / 22$ & -0.040 & 0.968 \\
\hline
\end{tabular}

Table 2 - Male and juvenile estimates of permanence rates and t-test results $\left(\mathrm{H}_{0}\right.$ : juvenile permanence $=$ adult permanence) of a population of Tropidurus torquatus from Brasília, Brazil. n, initial number of individuals.

\begin{tabular}{cccc}
\hline Period & Juveniles rate $(\mathbf{n})$ & Adults rate $(\mathbf{n})$ & $\mathbf{t}(\mathbf{p})$ \\
\hline May to November 1996 & $0.392(52.1)$ & $1.000(24.0)$ & $5.272(<0.01)$ \\
May to November 1997 & $0.178(107.0)$ & $0.271(38.9)$ & $0.943(0.35)$ \\
May to November 1998 & $0.170(53.0)$ & $0.563(10.7)$ & $2.364(0.02)$ \\
\hline
\end{tabular}

Table 3 - Male and female permanence rates from January to November and $t$-tests $\left(\mathrm{H}_{0}\right.$ : male permanence rate $=$ female permanence rate) of a population of Tropidurus torquatus from Brasília, Brazil. n, initial number of individuals.

\begin{tabular}{cccc}
\hline Year & Males rate $(\mathbf{n})$ & Females rate $(\mathbf{n})$ & $\mathbf{t}(\mathbf{p})$ \\
\hline 1996 & $0.217(22.7)$ & $0.096(51.6)$ & $1.042(0.30)$ \\
1997 & $0.111(19.8)$ & $0.158(18.3)$ & $-0.050(0.96)$ \\
\hline
\end{tabular}

Table 4 - Male and female permanence rates of the 1996 cohort and $t$-tests $\left(\mathrm{H}_{0}\right.$ : male permanence rate $=$ female permanence rate) of a population of Tropidurus torquatus from Brasília, Brazil. n, initial number of individuals.

\begin{tabular}{cccc}
\hline Period & Males rate $(\mathbf{n})$ & Females rate $(\mathbf{n})$ & $\mathbf{t}(\mathbf{p})$ \\
\hline 1996 to 1997 & $0.3333(15)$ & $0.5568(37)$ & $1.15(0.25)$ \\
1997 to 1998 & $0.6000(5)$ & $0.1053(19)$ & $1.80(0.07)$ \\
1996 to 1998 & $0.2000(15)$ & $0.0541(37)$ & $1.10(0.27)$ \\
\hline
\end{tabular}


population peaks and high numbers of incoming individuals in the population during periods with high incidence of hatchlings indicate that the population increase results principally from recruitment. Therefore, births are probably more important than immigration for the increase in population size of T. torquatus. A relationship between recruitment and population peaks also occurs in T. itambere (Van Sluys 2000) and in various lizard species with seasonal reproductive patterns, such as Liolaemus darwinii (Viana et al. 1994), Mabuya buettneri (Barbault 1976), and Anolis gingivinus and A. pogus (Roughgarden 1995).

Age structure of the population also varied seasonally. During the recruitment period, from March to June, there was a predominance of juveniles that were not recorded from November onward. These results are a consequence of the seasonal reproduction (Wiederhecker et al. 2002) and early age of maturity, estimated at five months for this species (Pinto 1999). The estimated initial cohort size is much larger than population size before recruitment in all three years. Therefore, the importance of juvenile recruitment for population size is basically due to the low permanence rates and the population annual reproductive success, as in Anolis limifrons (Andrews 1988). The predominance of juveniles, at least in part of the year, is typical of species with short life cycles (Barbault 1976, Ortega and Arriaga 1990, Howland 1992) resulting in a high annual turnover of individuals in the population.

Despite its marked monthly fluctuation, the instantaneous rate of natural increase did not differ from zero during the study period. A compilation of data from 29 species suggests that lizards maintain relatively constant population sizes when compared to other vertebrates (Schoener 1985). However, this statement is weakened because the author considered only species from temperate regions and islands and also species with longer life expectancies, resulting in a biased sample when considering lizards in general (Andrews 1988).
Lizard populations with short life cycles and high annual turnover of individuals should be more susceptible to large variations in population size among years (Andrews and Wright 1994, Bull 1994), directly reflecting the recruitment success during the reproductive period (Andrews 1988). A stable population size was also found in Tropidurus itambere (Van Sluys 2000) and Liolaemus lutzae (Rocha 1998), demonstrating that even species with short life cycles can maintain constant population sizes. The stability in these cases suggests that environmental fluctuations were not sufficient to affect drastically recruitment, maintaining population size.

Juveniles had a lower permanence rate than adults in 1996 and 1998. A lower juvenile permanence is common among lizards, tending to be higher for long-lived species (Hasegawa 1990). Disappearance of juveniles occurs mostly due to more potential predators of small organisms (Bull 1995) and the permanent emigration of individuals that reach sexual maturity (Stamps 1993, Parker 1994). In 1997, the adult permanence rate was lower in relation to other years and there was no significant difference between juvenile and adult permanence rates. This reveals that the relationship between permanence and age can vary through time. However, this variation did not affect the instantaneous rate of natural increase. The simultaneous occurrence of population size stability and permanence rate variation suggests the existence of densitydependent compensatory mechanisms (Sinclair and Pech 1996). For instance, in 1998, the population size was smaller in the months that preceded recruitment and the number of incoming individuals was larger in relation to 1996 and 1997, indicating that the lower density of adults favors the establishment of juveniles, as observed in Sceloporus graciosus (Tinkle et al. 1993).

In general, juvenile and adult permanence rates were low, indicating a large turnover of individuals in the population. Despite the 
maximum life expectancy estimation of about three years, most individuals did not survive more than a year. These characteristics are expected in species with short life cycles, indicating a low investment in maintenance and a high cost of reproduction (Tinkle 1969, Tinkle et al. 1970).

Considering the total number of captured individuals, the sex-ratio differed from 1:1. A female biased sex-ratio is common in polygynous species (Parker and Pianka 1975, Ballinger and Congdon 1981, Rose 1981) and can result from inter-sexual differences in the permanence rate and/or in the birth rate. In $T$. torquatus, the sex determination mechanism is of the XY:XX type, being genetically fixed (Kasahara et al. 1996). The expected sex-ratio at birth in species with this sort of mechanism is 1:1 (Smith 1989), in agreement with the sexratio found for juveniles, indicating that the asymmetry is caused by differences in the adult permanence rates. However, the adult permanence rate was not significantly larger for females, neither considering all individuals in the population nor only individuals of the 1996 cohort. This suggests that the sex-ratio deviation is a consequence of the lower permanence of males during a very short period, probably at the onset of secondary sexual characters. During this period, young males that reach sexual maturity would be susceptible to aggression by larger males, therefore being expelled to peripheral areas and unfavorable habitats (Stamps 1983).

With the exception of a few months during the reproductive period the sex-ratio in Tropidurus itambere did not deviate from 1:1 (Van Sluys 2000). In various lizard species the sex-ratio is related to the degree of polygyny (Schoener and Schoener 1980), being susceptible to variations on a temporal scale (Pianka 1970, Schoener and Schoener 1980) and also being directly correlated with the degree of sexual dimorphism (Stamps 1983). Considering the ratio between male and female size at maturity (male size / female size) as an indicator of sexual dimorphism (Stamps 1983), $T$. torquatus presents a slightly larger dimorphism than $T$. itambere $(70.0 / 65.0 \mathrm{~mm}=1.08$ and $57.3 / 56.1 \mathrm{~mm}=1.02$, respectively). If sexual dimorphism in these species is due to sexual selection, it is expected that T. torquatus has a larger degree of polygyny.

The development of polygyny depends on the temporal availability of receptive females and tends to be greater when the reproductive period is long, allowing dominant males to monopolize receptive females (Emlem and Oring 1977). However, females of $T$. itambere and $T$. torquatus have vitellogenic follicles for a similar amount of time (5 months). Therefore, there is no difference on the time availability of receptive females between the two species. Another factor that influences the degree of polygyny is population density. The overlap in home ranges of insectivore female lizards permits their agglomeration in favorable habitats, facilitating their monopoly by dominant males (Emlem and Oring 1977, Stamps 1983). In this manner, the larger the population density, the larger the number of females in relation to males, therefore, the higher the degree of polygyny (Schoener and Schoener 1980). For $T$. itambere, the mean density of individuals per hectare (52.3) (Van Sluys 2000) was lower in relation to T. torquatus (307.4), suggesting that differences between the two species can result from higher competition among males in the denser population, generating a female biased sex-ratio.

Another factor that may contribute to a proportional higher number of females in the population of $T$. torquatus is the greater size difference between established males (territory owners) and males at the onset of sexual maturity. The relation between asymptotic size and minimum reproductive size in males of the two species is $1.80(126.0 / 70.0 \mathrm{~mm})$ in $T$. torquatus and $1.68(96.0 / 57.3 \mathrm{~mm})$ in $T$. itambere. The higher value for $T$. torquatus suggests that males of this species that have just entered adulthood should possess a lower 
potential to displace older adults that already own territories.

Differences observed between $T$. itambere and $T$. torquatus can have origin either in proximate or genetic factors and the determination of prevalence for each one depends on long term studies and also on comparative studies involving populations from other localities, including those where the two species are sympatric. The studied population of T. torquatus had a short life expectancy, high recruitment rates, high juvenile mortality, high population turnover, and a female-biased sexratio. Overall, the observed data and the expectations of current life history theory for an early maturing and territorial species (Ballinger 1983, Dunham et al. 1988) are in agreement.

\section{Acknowledgments}

We thank A. Pinho, A. Sevilha, A. Pereira, A. Péres Jr., D. Mesquita, F. França, G.Vieira, L. Oliveira, and M. Mortari for invaluable assistance with field work. We also thank A. de Araújo, D. Rocha, M. Van Sluys, C.F.D. Rocha and R. Constantino, A. Gainsbury and L. Aguiar for invaluable criticisms on an earlier version of the manuscript. The Fundação Pólo Ecológico de Brasília kindly allowed us to develop fieldwork in the Santuário de Vida Silvestre do Riacho Fundo. This work was partially supported by graduate fellowships from Conselho Nacional de Desenvolvimento Científico e Tecnológico-CNPq to HCW and ACSP, and by a research fellowship from CNPq to GRC (\# 302343/88-1).

\section{References}

Adolph, S. C. and W. P. Porter. 1993. Temperature, activity and lizard life histories. The American Naturalist 142: 273-295.

Andrews, R. M. 1988. Demographic correlates of variable egg survival for a tropical lizard. Oecologia (Berlin) 76: $376-382$.
Andrews, R. M. and J. D. Nichols. 1990. Temporal and spatial variation in survival rates of the tropical lizard Anolis limifrons. Oikos 57: 215-221.

Andrews, R. M. and S. J. Wright. 1994. Long-term population fluctuations of a tropical lizard: a test of causality. Pp. 267-285 in L. J. Vitt and E. R. Pianka (eds.), Lizard Ecology - historical and experimental perspectives. Princeton, New Jersey. Princeton University Press.

Arnason, A. N., C. J. Schwarz and G. Boyer. 1995. POPAN - 4. A Data Maintenance and Analysis System for Mark-recapture Data, 4 v., Winnipeg, Canada. The University of Manitoba.

Ballinger, R. E. 1977. Reproductive strategies: food availability as a source of proximal variation in a lizard. Ecology 58: 628-635.

Ballinger, R. E. 1983. Life-history variations. Pp. 241-260 in R. B. Huey, E. R. Pianka and T. W. Schoener (eds.), Lizard Ecology - studies of a model organism. Cambridge, Massachusetts. Harvard University Press.

Ballinger, R. E. and J. D. Congdon. 1981. Population ecology and life history strategy of a montane lizard (Sceloporus scalaris) in southeastern Arizona. Journal of Natural History 15: 213-222.

Barbault, R. 1976. Population dynamics and reproductive patterns of three African skinks. Copeia 1976: 483490.

Bergallo, H. G. and C. F. D. Rocha. 1993. Activity patterns and body temperatures of two sympatric lizards (Tropidurus torquatus and Cnemidophorus ocellifer) with different foraging tactics in southeastern Brazil. Amphibia-Reptilia 14: 312-315.

Bergallo, H. G. and C. F. D. Rocha. 1994. Spatial and trophic niche differentiation in two sympatric lizards (Tropidurus torquatus and Cnemidophorus ocellifer) with different foraging tactics. Australian Journal of Ecology 19: 72-75.

Bull, C. M. 1994. Population dynamics and pair fidelity in sleepy lizards. Pp. 159-174 in L. J. Vitt and E. R. Pianka (eds.), Lizard Ecology - historical and experimental perspectives. Princeton, NJ. Princeton University Press.

Bull, C. M. 1995. Population ecology of the sleepy lizard, Tiliqua rugosa, at Mt. Mary, South Australia. Australian Journal of Ecology 20: 393-402.

Cruz, F. B. 1997. Reproductive activity in Tropidurus etheridgei in the semiarid Chaco of Salta, Argentina. Journal of Herpetology 31: 444-450.

Dunham, A. E., D. B. Miles and D. N. Reznick. 1988. Life history patterns in squamate reptiles. Pp. 441-522 in C. Gans and R. B. Huey (eds.), Biology of the Reptilia, Vol. 16, Ecology B. Defense and Life History. New York. Alan R. Liss, Inc. 
Emlem, S. T. and L. W. Oring. 1977. Ecology, sexual selection and the evolution of mating systems. Science 197: 215-223.

Ferguson, G. W., C. H. Bohlen and H. P. Wooley. 1980. Sceloporus undulatus: comparative life history and regulation of a Kansas population. Ecology 61: 313322.

Frost, D. R. 1992. Phylogenetic analysis and taxonomy of the Tropidurus group of lizards (Iguania: Tropiduridae). American Museum Novitates 3033: 1-68.

Giaretta, A. A. 1996. Lacertilia: Tropidurus torquatus (NCN). Home range. Herpetological Review 27: 8081 .

Haffer, J. 1987. Quaternary history of tropical America. Pp. 1-18 in T. C. Whitmore and G. T. Prance (eds.), Biogeography and Quaternary History in Tropical America. Oxford. Clarendon Press.

Hasegawa, M. 1990. Demography of an island population of the lizard, Eumeces okadae, on Miyake-Jima, Izu Islands. Research on Population Ecology 32: 119-133.

Howland, J. M. 1992. Life history of Cophosaurus texanus (Sauria: Iguanidae): environmental correlates and interpopulational variation. Copeia 1992: 82-93.

Huey, R. B., E. R. Pianka and T. W. Schoener. 1983. Lizard Ecology - studies of a model organism. Cambridge, Massachusetts. Harvard University Press. 501 pp.

Jolly, G. M. 1965. Explicit estimates from capturerecapture data with both death and immigrationstochastic model. Biometrica 52: 225-247.

Kasahara, S., K. C. M. Pellegrino, M. T. Rodrigues and Y. Yonenaga-Yassuda. 1996. Comparative cytogenetic studies of eleven species of the Tropidurus torquatus group (Sauria, Tropiduridae), with banding patterns. Hereditas 125: 37-46.

Ortega, A. and L. Arriaga. 1990. Seasonal abundance, reproductive tactics and resource partitioning in two sympatric Sceloporus lizards (Squamata: Iguanidae) of Mexico. Revista de Biologia Tropical 38: 1491-1495.

Parker, W. S. 1994. Demography of the fence lizard, Sceloporus undulatus, in northern Mississippi. Copeia 1994: 136-152.

Parker, W. S. and E. R. Pianka. 1975. Comparative ecology of populations of the lizard Uta stansburiana. Copeia 1975: 615-632.

Pianka, E. R. 1970. Comparative autecology of the lizard Cnemidophorus tigris in different parts of its geographic range. Ecology 51: 703-720.

Pinto, A. C. S. 1999. Dimorfismo sexual e comportamento sexual em Tropidurus torquatus (Squamata, Tropiduridae) no Brasil Central. Unpublished M.Sc. Dissertation, Universidade de Brasília, Brazil.
Rocha, C. F. D. 1998. Population dynamics of the endemic tropidurid lizard Liolaemus lutzae in a tropical seasonal restinga habitat. Ciência e Cultura 50: 446451.

Rocha, C. F. D. and H. G. Bergallo. 1990. Thermal biology and flight distance of Tropidurus oreadicus (Sauria Iguanidae) in an area of Amazonian Brazil. Ethology, Ecology and Evolution 2: 263-268.

Rocha, C. F. D. and H. G. Bergallo. 1992. Population decrease: the case of Liolaemus lutzae, an endemic lizard of southeastern Brazil. Ciência e Cultura 44: 52-54.

Rodrigues, M. T. 1987. Systematics, ecology, and zoogeography of the Tropidurus of the torquatus group south of the Amazon River [South America] (Sauria, Iguanidae). Arquivos de Zoologia, São Paulo 31: 105-230.

Rose, B. 1981. Factors affecting activity in Sceloporus virgatus. Ecology 62: 706-716.

Roughgarden, J. (ed.). 1995. Anolis Lizards of the Caribbean: ecology, evolution, and plate tectonics. New York. Oxford University Press. 200 pp.

Schoener, T. W. 1985. Are lizards population sizes unusually constant through time? The American Naturalist 126: 633-641.

Schoener, T. W. and A. Schoener. 1980. Densities, sex ratios, and population structure in four species of Bahamian Anolis lizards. Journal of Animal Ecology 49: $19-53$.

Sinclair, A. R. E. and R. P. Pech. 1996. Density dependence, stochasticity, compensation and predator regulation. Oikos 75: 164-173.

Smith, G. R. 1996. Annual life-history variation in the striped plateau lizard, Sceloporus virgatus. Canadian Journal of Zoology 74: 2025-2030.

Smith, J. M. 1989. Evolutionary Genetics. New York. Oxford University Press. 321 pp.

Stamps, J. A. 1983. Sexual selection, sexual dimorphism, and territoriality. Pp. 169-204 in R. B. Huey, E. R. Pianka and T. W. Schoener (eds.), Lizard Ecology studies of a model organism. Cambridge, Massachusetts. Harvard University Press.

Stamps, J. A. 1993. Sexual size dimorphism in species with asymptotic growth after maturity. Biological Journal of the Linnean Society 50: 123-145.

Stearns, S. C. 1992. The Evolution of Life Histories. Oxford. Oxford University Press. 249 pp.

Tinkle, D. W. 1969. The concept of reproductive effort and its relation to the evolution of life histories of lizards. The American Naturalist 103: 501-516.

Tinkle, D. W., A. E. Dunham and J. D. Congdon. 1993. Life history and demographic variation in the lizard 
Sceloporus graciosus: a long-term study. Ecology 74 : 2413-2429.

Tinkle, D. W., H. M. Wilbur and S. G. Tilley. 1970. Evolutionary strategies in lizard reproduction. Evolution 24: 55-74.

Van Sluys, M. 1993a. Food habits of the lizard Tropidurus itambere (Tropiduridae) in southeastern Brazil. Journal of Herpetology 27: 347-351.

Van Sluys, M. 1993b. The reproductive cycle of Tropidurus itambere (Sauria, Tropiduridae) in Southeastern Brazil. Journal of Herpetology 27: 28-32.

Van Sluys, M. 2000. Population dynamics of the saxicolous lizard Tropidurus itambere (Tropiduridae) in a seasonal habitat of Southeastern Brazil. Herpetologica 56: $55-62$.

Van Sluys, M., C. F. D. Rocha and S. C. Ribas. 1994. Nematodes infecting the lizard Tropidurus itambere in southeastern Brazil. Amphibia-Reptilia 15: 405-408.

Viana, M. L., C. Joanovich and P. Váldes. 1994. Densidad, proporción de sexos y utilizacion del espacio de Liolaemus darwinii (Sauria: Iguanidae) en Valle de Tin Tin, Argentina. Revista de Biologia Tropical 42: 281287.
Vieira, G. H. C., H. C. Wiederhecker, G. R. Colli, and S. N. Báo. 2001. Spermiogenesis and testicular cycle of the lizard Tropidurus torquatus (Squamata: Tropiduridae) in the Cerrado of central Brasil. Amphibia-Reptilia 22: 217-233.

Vitt, L. J. and S. R. Goldberg. 1983. Reproductive ecology of two tropical iguanid lizards: Tropidurus torquatus and Platynotus semitaeniatus. Copeia 1983: 131-141.

Vitt, L. J., P. A. Zani and J. P. Caldwell. 1996. Behavioural ecology of Tropidurus hispidus on isolated rock outcrops in Amazonia. Journal of Tropical Ecology 12: 81-101.

Wiederhecker, H. C., A. C. S. Pinto and G. R. Colli. 2002. Reproductive ecology of Tropidurus torquatus (Squamata: Tropiduridae) in the highly seasonal Cerrado biome of central Brazil. Journal of Herpetology 36: $82-91$.

Zar, J. H. 1984. Biostatistical Analysis, 2nd ed. Englewood Cliffs, New Jersey. Prentice-Hall. 718 pp.

Zug, G. R. 1993. Herpetology - an introductory biology of amphibians and reptiles. San Diego. Academic Press, 527 pp. 